\title{
Determinants of Corporate Environment, Social and Governance (ESG) Reporting among Asian Firms
}

\author{
Rashidah Abdul Rahman *(D) and Maha Faisal Alsayegh \\ Department of Accounting, Faculty of Economics and Administration, King Abdulaziz University, \\ Jeddah 21589, Saudi Arabia; mfalsayegh@kau.edu.sa \\ * Correspondence: rabdulwahid@kau.edu.sa
}

\begin{abstract}
Departing from previous studies, which have mostly focused on Western countries, our work investigates the determinants of the corporate environment, social and governance (ESG) reporting among Asian firms. Examining Asian public listed firms from 2005 to 2017, our crosssectional model results indicate that firm characteristics (economic performance, profitability, leverage and size) are found to disclose additional ESG information. The outcome is consistent with the legitimacy theory, which posits that firms provide higher ESG reporting to legitimize and justify the firm's continuous existence. The findings are important for firms, stakeholders and policymakers. While firms may formulate ways to improve ESG reporting to compete in the international market, the stakeholders may pressure firms to disclose more information on ESG and policymakers to designalegal framework on ESG that suits firms in Asia.
\end{abstract}

Keywords: corporate sustainability reporting; environment; social; governance; Asian companies; determinants; economic performance

Citation: Abdul Rahman, Rashidah, and Maha Faisal Alsayegh. 2021.

Determinants of Corporate

Environment, Social and Governance (ESG) Reporting among Asian Firms. Journal of Risk and Financial Management 14: 167. https:// doi.org/10.3390/jrfm14040167

Academic Editors: Khaled Hussainey and Stephen Satchell

Received: 6 March 2021

Accepted: 6 April 2021

Published: 8 April 2021

Publisher's Note: MDPI stays neutral with regard to jurisdictional claims in published maps and institutional affiliations.

\section{Introduction}

As the demands for corporate transparency and accountability for the environment, social and governance (ESG) reporting have dramatically increased over the last few decades, firms have put in efforts towards internal improvement by adopting sustainable and socially responsible policies and reporting them to stay competitive. The concept of environment, social and governance (ESG) reporting has been expressed in various interchangeable terms, including non-financial reporting, corporate sustainability report (CSR); corporate social responsibility disclosure (CSRD); economic, governance, social, ethical, and environmental (EGSEE) report (Hahn and Kuhnen 2013; Rezaee 2016; Jain et al. 2016). The report essentially functions as a communication tool between organizations and investors, clients and various stakeholder groups in society by providing information that the organizations integrating environmental, social, governance, ethical, consumer and human rights concerns into their business strategies and operations, a feature, which is otherwise not entirely captured in corporate financial statements. ESG reporting is a means of communicating to the community that the organization is not gearing its business towards the pursuit of pure profit at the expense of fulfillingitsobligations to its employees, their customers, the environment and the society at large.

Researchers have claimed that the benefits associated with integrating sustainability into their business strategy and practices and improving their sustainability reporting include an increase in transparency, improved reputation and legitimacy, enhanced brand value, increased employee and customer loyalty, reduced costs, better business practices, improved firm performance and valuation, and competitive advantage generation (Herzig and Schaltegger 2006; Ioannou and Serafeim 2017; Sanchez-Planelles et al. 2021). In fact, Brooks and Oikonomou (2018) and Xie et al. (2019) have shown a strong correlation between the companies that provide sustainable reports and firm performance. Our previous study (Alsayegh et al. 2020) confirmed that Asian corporations that disclosed their ESG practices 
enhance their corporate sustainability performance (economic, environmental and social (EES) performance). However, little theoretical attention has been placed on understanding the reasons why corporations behave in a responsible way. Caputo et al. (2017) examined the forces that drive companies to introduce a sustainability report within SMEs in Italy, while other studies (example, Jackson et al.; Mion and Adaui 2019) focused on the factors affecting the quality and the level of non-financial reporting during the transition from a voluntary to a mandatory, especially due to the increased complexity as a result of the new legislation. This is the consequence of implementing the Directive 2014/95/EU that makes it mandatory for all public entities operating in European countries to disclose non-financial information. As these disclosures are largely voluntary among companies in Asia, the factors that determine their ESG disclosure remain unclear. Hence, the current study's primary aim is to empirically investigate the motivations and drivers for corporations in Asia forengaging in ESG reporting endeavors. Building on this research, our study contributes new empirical insights about the factors influencing ESG reporting initiation in Asia. An in-depth understanding of ESG reporting determinants is deemed important to further improve the development of the ESG reporting framework in Asia.

Our motivation behind the choice of this particular context is our interest in Asia. The last years have seen an increase in ESG reporting, mainly in developed Western economies, and that reporting is now becoming increasingly relevant in Asia (Alsayegh et al. 2020). However, the literature on ESG reporting in Asia remains limited in quantity. Most Asian economies can be characterized as developing with various stages of development. Japan is an economically developed country, but some countries, such as Afghanistan, Cambodia and Nepal, are impoverished. Three Asian countries are includedamong the world's four largest economies: Japan, China and India. Excluding Japan, the region's share of the global gross domestic product (GDP) rose from approximately $10 \%$ in 1980 to $36 \%$ in 2019 (GIC Report 2018-2019). As Asia is the rising star of global economic activity, examining ESG research among Asian companies would be timely.

This study provides a further understanding of the motivations in corporate sustainability reporting among Asian firms. Extensive research has been undertaken in this particular area, but the related studies have typically tended to focus on the determinants of CSR reporting in Western countries or in individual countries in Asia. In the literature review study, Ali et al. (2017) found that determinants of CSR disclosure studies in developing countries are dominated by single-country studies, including Malaysia, Singapore, and China. For example, Baba (2017); Haniffa and Cooke (2005) are among studies that have examined the determinants of CSR disclosure in Malaysia; Hossain and Reaz (2007), Joshi and Hyderabad (2018) in India; Wang et al. (2013) in China; and Menassa and Dagher (2020) in the United Arab Emirates. Unlike these studies, our study focuses on the factors driving ESG disclosure among 1244 companies in 20 Asian countries during the period 2005-2017. In examining the public listed companies in Asian countries, this work contributes to the existing ESG disclosure literature in Asia. Further, the philosophical and ideological underpinning of ESG reporting is rooted in Anglo-American and European principles of liberal democratic rights, justice and societal structures. ESG reporting by Asian corporations may differ from their counterparts in the West as the former is shaped by their colonial and non-colonial experiences and by their ethnicities and religious diversity.

In addition, previous studies have paid more attention to either environmental disclosure or a combination of environment and social disclosure. Similar to the study by Alsayegh et al. (2020), the present study encompasses all three dimensions of ESG (environment, social and governance aspects). By adopting legitimacy theory as the premise of our theoretical framework, we seek to examine if firm economic performance, profitability, leverage and size may drive management towards voluntary disclosure of ESG information. Previous research that utilized legitimacy theory (e.g., Haniffa and Cooke 2005; Chih et al. 2010; Cuganesan et al. 2007; Dyduch and Krasodomska 2017; Ali et al. 2017; Magali et al. 2020) in relation to social and environmental or sustainability reporting indicate that organizations increase corporate reporting when they perceive the existence 
of a legitimacy gap, which is when the needs of the organization are not in compliance with the expectations and norms of the community. Further, the legitimacy theory has been adopted to identify the determinants that induce variability in corporate ESG reporting to legitimize their business, an aspect, which is the focus of this study.

Like Alsayegh et al. (2020), we construct an ESG disclosure score from the Bloomberg ESG database for 1244 Asian firms over 12 years (2005-2017). Data for the firm characteristics of economic performance, profitability, leverage and size were gathered from the Thomson Reuters Asset 4 dataset. We confirm that Asian firms that are larger and have high economic performance, higher profitability and higher leverage and affect ESG reporting. Our results are consistent with the legitimacy theory, which posits that Asian firms report more ESG information to gain and maintain licenses to operate.

The remainder of this article is organized as follows: The literature review and hypotheses development are provided in the next section. The Methodology then follows in the third section, and the descriptive results and findings are discussed in the fourth section. The last section summarizesthe key findings of this work with a discussion of implications.

\section{Literature Review and Hypotheses Development}

No generally accepted theory exists for explaining voluntary disclosure practices, but the legitimacy theory is the current dominating perspective in ESG literature to explain or predict particular managerial sustainability reporting practices (Gray et al. 1995; Hooghiemstra 2000; Dyduch and Krasodomska 2017; Mousa and Hassan 2015; Deegan 2002; Deegan 2019). Suchman (1995, p. 574) described legitimacy theory as "a generalised perception or assumption that the actions of an entity are desirable, proper, or appropriate within some socially constructed system of norms, values, beliefs, and definitions". That is, the organization must continuously demonstrate that its actions are seen as "legitimate" and that societies perceive them as operating within the accepted bounds and norms. Legitimacytheory purports that an organization would voluntarily report on activities as a communication tool, such as disclosing particular ESG information items if management perceived that those activities were expected by the societies in which the organization operates. Researchers employing this legitimacy framework also suggest that ESG disclosures are responses to public pressure and negative media attention or social visibility requirements resulting from major social incidents, such as environmental phenomena, violation of human rights and lawsuits against the organizations (Walden and Schwartz 1997; Hahn and Kuhnen 2013; Rezaee 2016). As corporate reputation is of prime importance, the increase in voluntary disclosure represents the organization's strategy togain and maintain a license to operate. Further, the organizations should continually seek to ensure that they operate within the expectations and norms of various stakeholder groups in society, rather than only in investors' expectations and norms.

Therefore, a central aspect of thelegitimacy theory is the social contract between the organization and the society or community in which it operates (Guthrie and Parker 1989; Deegan 2006; Deegan and Samkin 2009). When the community finds that the organization's activities do not respect its moral values, the contract may be revoked and may even lead to the organization's failure. Deegan (2006) stated that an organization's survival would be threatened if a legitimacy gap exists, such that the expectations and norms of society are incongruent with the needs of the organization. In cases where the community posits that the organization has breached its social contract, Deegan (2006, p. 163) indicates the following consequences: consumers may reduce the demand for the organization's products; factory suppliers may eliminate the supply of labor and financial capital to the business; or constituents may lobby government for increased taxes, fines or laws to prohibit those actions, which do not conform with the expectations of the community. Hence, the organization must justify its survival through legitimate economic and social actions that do not jeopardize the existence of the society and the environment in which it operates. 
When a legitimacy gap exists, one of the ways organizations may take remedial action to become legitimate is to increase corporate disclosure (Deegan 2006; Cuganesan et al. 2007; Rezaee 2016). Given the significance of ESG reporting for sustainable development and the success of an organization, various stakeholder groups have demanded more ESG information. Hence, the legitimacy theory is used in this study as a mechanism that supports organizations in implementing, developing and voluntarily reporting ESG information for firms to convince their communities that their organizations are socially responsible. Firms disclose their sustainability strategy practices establishing that their products and services are desirable and beneficial to various stakeholder groups, thereby achieving their legitimacy in society. Compliance with societal expectations is seen as significant and could result in ensuring continued inflows of capital, labor and customers (Pfeffer and Salancik 1978) and assisting in closing the legitimacy gap. Prior empirical research (e.g., Haniffa and Cooke 2005; Cuganesan et al. 2007; Dyduch and Krasodomska 2017; Ali et al. 2017) examined legitimacy theory and its applicability to understanding voluntary disclosure practices of companies. The results of these studies tend to support the applicability of legitimacy theory to provide insight into management disclosure behavior.

Further, management may have different motivations towards legitimation because of how management themselves perceive society's opinion about them and also mainly due to the different perceptions that society has concerningthe organization's activities. To achieve legitimization, organizations adopt disclosure policies that may differ according to their characteristics. Fifka (2013), Hahn and Kuhnen (2013) and Ali et al. (2017) are among previous studies that review the factors that may cause variability in voluntary corporate disclosure. In examining 76 empirical research articles, Ali et al. (2017) found that firm characteristics (company size, industry sector, profitability and corporate governance mechanisms), specific stakeholders (regulators, shareholders, creditors, investors, environmentalists and media) and external forces (international buyers, foreign investors, international media and international regulatory bodies) are perceived to drive the corporate social reporting agenda. Other studies (e.g., Gamerschlag et al. 2010; Chih et al. 2010; Fifka 2013; Hahn and Kuhnen 2013; Dyduch and Krasodomska 2017) have also investigated the motivations that lead companies to disclose corporate sustainability information.

In this study, we analyze the consequences of firm economic sustainability performance, firm profitability, leverage and size on ESG reporting.

\subsection{Economic (ECN) Sustainability Performance (ESP)}

Economic sustainability performance in this study reflects the best use of management practices in supporting the continued success of the firm's economic growth in generating long-term shareholder value without negatively impacting its social, environment and the community at large. It entails the capability of the organization to maximize longterm profitability through its operational effectiveness and efficiency. Firms with high economic sustainability performance will disclose more ESG information to legitimize their existence. Hummel and Schlick (2016) and Deegan (2002) are among the studies that found evidence that poor sustainability performance firms disclose low-quality sustainability disclosure (information that is opaque and superficial) to disguise their poor sustainability performance whileattempting to remain legitimate.

Based on the legitimacy theory that firms with higher economic sustainability performance disclose more ESG information in congruence with social responsibilities, our hypothesis is as follows:

Hypothesis 1 (H1). Economic sustainability performance has a positive impact on ESG reporting.

\subsection{Profitability}

Profitable companies face higher social constraints and public pressure to explain that their actions are legitimate than less profitable counterparts because being associated with actions that breach society's expectation sare costly. Hence, Campbell (2007), Chih 
et al. (2010) and Gamerschlag et al. (2010) indicate that corporations are more likely to act in socially responsible ways by reporting higher ESG information when their financial statements reveal favorable financial performance. Further, profitable corporations have the resources and the ability to bear the costs that are associated with investments in exposing ESG information more extensively to their community, thereby legitimizing their existence.

Although empirical studies by Chih et al. (2010) and Dyduch and Krasodomska (2017) did not find a significant link between corporate financial performance and CSR, studies by Roberts (1992); Haniffa and Cooke (2005); Gamerschlag et al. (2010) and Menassa and Dagher (2020) found that companies are more likely to disclose CSR information when they are experiencing the relatively favorable financial performance.

According to legitimacy theory, which posits that firms with higher financial performance disclose more ESG information in line with societal concerns, we propose the following hypothesis:

Hypothesis 2 (H2). Firm profitability has a positive impact on ESG reporting.

\subsection{Leverage}

A survey by the European Leveraged Finance Association indicates that $72 \%$ of the 100 leveraged loan and high-yield bond buyers interviewed address ESG considerations as part of their investment decisions (Ho 2020). Topics of interest among the credit investors include greenhouse gas emission, detail on off-balance-sheet environmental liabilities, compliance with labor and human rights, and management compensation structure. Further, Weber (2012) and Herbohn et al. (2019) found evidence that banks provide favorable financial terms to firms that disclose high carbon risk information to investors. Hummel and Schlick (2016) also confirmed that loan borrowers prefer firms with higher sustainable disclosure and that they are unwilling to accept low-quality information. Thus, highly leverage firmsare prone to be scrutinized by debt holders and pressured to disclose more ESG information to provide evidence of their legitimacy and assurance on the financial success of the firm.

Accordingly, we posit the hypothesis below.

Hypothesis 3 (H3). Firm leverage has a positive impact on ESG reporting.

\subsection{Size}

As mentioned earlier, the main focus of legitimacy theory is the interaction between corporations and community and the environment in which it operates. Corporations disclose more non-financial information to satisfy society's demand as the theory suggests that failure to comply with social norms endangers a firm legitimacy and its financial sustainability. Hence, multiple studies over the past decades have analyzed and confirmed that larger corporations are likely to act more socially responsible and report higher ESG information as they are subject to closer scrutiny from the public and socially sensitive special interest groups and are more vulnerable to adverse reactions than smaller corporations (Meek et al. 1995; Branco and Rodrigues 2008; Hahn and Kuhnen 2013; Magali et al. 2020). As corporate reputation is more significant for larger firms because of their more diverse interest groups, they must increase ESG reporting to be seen as legitimate and in line with good corporate citizenship. Unlike smaller firms that lack resources to invest in analysis and reporting initiatives, larger firms have more resources, more activities to report and encounter lower cost of preparing ESG report due to economies of scale. As Hackston and Milne (1996, p. 81) argued, "larger companies undertake more activities, make a greater impact on society, and have more shareholders who might be concerned with social programs undertaken by the company".

Meek et al. (1995); Haniffa and Cooke (2005); Chih et al. (2010); Gamerschlag et al. (2010); Dyduch and Krasodomska (2017) and Menassa and Dagher (2020) are among previ- 
ous empirical studies that confirm that larger firms report higher sustainability disclosure. As the public pays more attention to larger firms relative to smaller-sized counterparts, the former are pressured to disclose more ESG information in demon strating to the public at large that they are implementing their social responsibilities. Consequently, we posit the following hypothesis.

Hypothesis $4 \mathbf{( H 4 ) . ~ F i r m ~ s i z e ~ h a s ~ a ~ p o s i t i v e ~ i m p a c t ~ o n E S G ~ r e p o r t i n g . ~}$

\section{Sample, Data and Research Design}

Gathered from the Thomas Reuters Datastream, Table 1 highlights the number of public listed companies in Asian countries in the sample from 2005-2017. Similar to the sample used by Alsayegh et al. (2020), only 21 out of the total 48 countries in Asia were found in the datastream. The three Asian countries that rank among the world's four largest economies (Japan, China and India) are part of the sample. By excluding subjects with missing data, 1244 companies with 9954 firm-year observations provide the final sample for the study.

Table 1. Sample of public listed companies in Asian countries from 2005 to 2017.

\begin{tabular}{|c|c|c|c|c|}
\hline Country & No. Firm & Percentage Firm & No. Observation & Percentage Observation \\
\hline Bahrain & 6 & $0.48 \%$ & 12 & $0.12 \%$ \\
\hline China & 156 & $12.54 \%$ & 981 & $9.86 \%$ \\
\hline Cyprus & 1 & $0.08 \%$ & 12 & $0.12 \%$ \\
\hline Hong Kong & 119 & $9.57 \%$ & 998 & $10.03 \%$ \\
\hline India & 91 & $7.32 \%$ & 560 & $5.63 \%$ \\
\hline Indonesia & 34 & $2.73 \%$ & 201 & $2.02 \%$ \\
\hline Israel & 16 & $1.29 \%$ & 99 & $0.99 \%$ \\
\hline Japan & 399 & $32.07 \%$ & 4307 & $43.27 \%$ \\
\hline Korea (South) & 110 & $8.84 \%$ & 704 & $7.07 \%$ \\
\hline Kuwait & 7 & $0.56 \%$ & 21 & $0.21 \%$ \\
\hline Macau & 3 & $0.24 \%$ & 19 & $0.19 \%$ \\
\hline Malaysia & 45 & $3.62 \%$ & 290 & $2.91 \%$ \\
\hline Oman & 4 & $0.32 \%$ & 7 & $0.07 \%$ \\
\hline Philippines & 21 & $1.69 \%$ & 129 & $1.30 \%$ \\
\hline Qatar & 9 & $0.72 \%$ & 32 & $0.32 \%$ \\
\hline Singapore & 40 & $3.22 \%$ & 411 & $4.13 \%$ \\
\hline Taiwan & 121 & $9.73 \%$ & 822 & $8.26 \%$ \\
\hline Thailand & 32 & $2.57 \%$ & 168 & $1.69 \%$ \\
\hline Turkey & 20 & $1.61 \%$ & 139 & $1.40 \%$ \\
\hline \multirow[t]{2}{*}{ United Arab Emirates } & 10 & $0.80 \%$ & 42 & $0.42 \%$ \\
\hline & 1244 & $100 \%$ & 9954 & $100 \%$ \\
\hline
\end{tabular}

Source: Alsayegh et al. (2020).

Next, we propose appropriate measures to proxy for the determinants of ESG disclosure in our empirical work. Previous studies adopt the number of pages or sentences that contain ESG information in the annual report (e.g., Adams et al. 1998; Haniffa and Cooke 2005; Weber 2014) or by using the ESG database provided by other providers, such as Thomson Reuters ESG data; Bloomberg ESG data; MSCI ESG Research; and DowJones Sustainability Index (Zhao et al. 2018; Taliento et al. 2019), to measure the level of ESG. Similar to Ioannou and Serafeim (2017), Xie et al. (2019) and Alsayegh et al. (2020), we obtain the information on ESG disclosure score from the Bloomberg ESG database for 1244 companies for the fiscal years 2006-2017. The Bloomberg ESG database provides ESG information that originates from companies' annual reports, sustainability reports, company websites, press releases and third-party surveys that request information directly from companies. The transparency of the data can be traced back to their original sources in company documents. Some data points contribute more "weight" than others due to their 
importance and type of industry. The weighted ESG disclosure score and its sub-scores (environmental, social, and governance) range from 0.1 to 100 . A score of 0.1 is given if the companies disclose the minimum amount of ESG data. If the companies provide all the variables required by Bloomberg, then it wasgiven a score of 100 .

The ESG information in Bloomberg was calculated according to the ESG disclosure score and its three sub-scores: the environment $(E)$, social $(S)$ and governance $(G)$ scores. For example, environment data include information on emission reduction, resource reduction and product innovation, particularly on water, waste, energy and operational policies around environmental impact. Social data include employment quality, safety and health, training and development, human rights, and product responsibility that has an impact on communities. Governance information includes board structure, compensation policy, shareholder rights, vision and strategy, the company's political involvement and board function.

Similar to Jitmaneeroj (2016); Bajic and Yurtoglu (2018), and Alsayegh et al. (2020), we obtained the information on economic sustainability performance (ECN), profitability, leverage and size from the Thomas Reuters Datastream. For an in-depth understanding of the impact of these firm characteristics on ESG reporting, we used a one-period lag of ECN, profitability, leverage and size, which is for the period 2005-2016.

Table 2 provides the definitions of variables and related data sources for all variables used in this study.

Table 2. Definitions of variables and corresponding data sources.

\begin{tabular}{|c|c|c|}
\hline Dependent Variable: & Definition & Data Sources \\
\hline $\begin{array}{l}\text { Environment, social andgovernance disclosure } \\
\text { (ESG) }\end{array}$ & $\begin{array}{l}\text { The composite ESG disclosure score and its sub-scores } \\
\text { (environmental, social, and governance) range from } 0.1 \text { to } \\
\text { 100. A score of } 0.1 \text { is given if the companies disclose the } \\
\text { minimum amount of ESG data. If the companies provide all } \\
\text { the variable required by Bloomberg, then it is given a score } \\
\text { of } 100 \text { (Ioannou and Serafeim 2017; Alsayegh et al. 2020) }\end{array}$ & Bloomberg \\
\hline \multicolumn{3}{|l|}{ Independent Variables: } \\
\hline $\begin{array}{l}\text { Economic sustainability performance } \\
\qquad(\mathrm{ECN})\end{array}$ & $\begin{array}{l}\text { Economic (ECN) sustainability performance data consider } \\
\text { various inputs such as shareholder loyalty, shareholders } \\
\text { performance, client loyalty in generating sustainable growth } \\
\text { and long-term shareholder value.The ECN performance } \\
\text { score ranges from } 0 \text { to } 100 \text {, indicating from poor to good } \\
\text { performance (Alsayegh et al. 2020) }\end{array}$ & Thomson Reuters \\
\hline Profitability & Return on assets (ROA) & Thomson Reuters \\
\hline Leverage & $\begin{array}{l}\text { Leverage (LEV) or debt ratio is measured by the average } \\
\text { debt toequity ratio. }\end{array}$ & Thomson Reuters \\
\hline Size & The natural logarithm of a firm's total assets & Thomson Reuters \\
\hline
\end{tabular}

Similar to Chih et al. (2010) and Alsayegh et al. (2020), we used multiple linear regressions for the sample of 1244 Asian companies (9954 firm-year observations for 20052017) to test the extent to which firm and financial characteristics have an impact on the likelihood of firms engaging in ESG disclosure:

Environment, social and governance (ESG) sustainability disclosure $=\alpha_{0}+\Sigma \beta_{1} \mathrm{ECN}$

$$
+\Sigma \beta_{2} \text { Profitability }_{\mathrm{i}}+\Sigma \beta_{3} \mathrm{LEV}_{\mathrm{i}}+\Sigma \beta_{4} \text { Size }_{\mathrm{i}}+\varepsilon,
$$

where the dependent variable is expressed as a score of ECG sustainability disclosureandreflects the level of ESG information disclosed by the corporations. The ESG score obtained from Bloomberg represents the composite components of the environment $(\mathrm{E})$, social (S) and governance $(G)$ disclosure information practices for a sample of 1244 Asian companies from 2005 to 2017. The weighted ESG sustainability disclosure score and its sub-scores (environmental, social, and governance) range from 0.1 to 100 . A score of 0.1 
is given if the companies disclose the minimum amount of ESG data. If the companies provide all the variables required by Bloomberg, then it is given a score of 100 .

The determinant variables, economic (ECN) sustainability performance, firm profitability, leverage (LEV) andsize, are retrieved from the Thomson Reuters database. Economic (ECN) sustainability performance data are non-financial based detail. ECN considers various inputs, such as shareholder loyalty, shareholder performance and client loyalty, in generating long-term shareholder wealth (Escrig-Olmedo et al. 2017; Jitmaneeroj 2016; Alsayegh et al. 2020). This variable indicates that through the use of best management practices, the company can generate sustainable growth and long-term return on investment. The ECN performance score ranges from 0 to 100, indicating from poor to good performance.

In this study, firm profitability was measured by return on assets (ROA) as an indicator of how profitable a company is relative to its total assets (Simnett et al. 2009; Chih et al. 2010). The ROA ratio is used to describe the efficiency of a company isutilizing its assets for its operational activities.Leverage (LEV) or debt ratiois measured by the average debtto-equity ratio (Roberts 1992; Casey and Grenier 2015; Alsayegh et al. 2020) to capture the importance of creditors as stakeholders relative to equity investors. Similar to Reverte (2009) and Hossain and Reaz (2007), this work used the natural logarithm of a firm's total assets as a proxy for size.

To address the endogeneity problem, we used lagged independent variables in the regression. It is reasonable to believe that the effect of ECN performance, leverage, size and firm performance will be reflected in the next year's ESG sustainability disclosure. Hence, this study used a one-period lag of ECN performance, leverage, size and firm performance information, which was for 2005-2016, and for ECG sustainability disclosure data from 2006-2017. Further, the study also applied the three static panel approaches, namely, the pooled ordinary least squares (OLS), fixed-effects and random-effects model, to address endogeneity problems.

\section{Empirical Results}

Table 3 summarizes the descriptive statistics for all variables used for the 9954 firmyear observations in our sample from 2005 to 2017. As shown in Table 3, there is a significant panel data variation in the ESG sustainability disclosure for the Asian firms, ranging from 3.43 to 91.20 and with a mean (median) score of 41.79 (38.4). In examining 65 Indian public listed firms for 2015-2017, Dalal and Thaker (2019) found mean (median) ESG scores of 59.10 (58.0), ranging from 0 to 94 . Taliento et al. (2019), however, found a relatively high ESG mean (median) disclosure score of 71.34 (72.0) among European companies in their sample.

Table 3. Descriptive statistics.

\begin{tabular}{cccccccc}
\hline Variable & Mean & Median & Maximum & Minimum & Std. Dev. & Skewness & Kurtosis \\
\hline ESG & 41.79 & 38.40 & 91.20 & 3.43 & 30.04 & 0.17 & 1.48 \\
ECN & 46.74 & 44.41 & 95.82 & 2.99 & 30.10 & 0.12 & 1.61 \\
LEVERAGE (\%) & 0.23 & 0.21 & 0.67 & 0 & 0.18 & 0.57 & 2.52 \\
ROA (\%) & 0.068 & 0.05 & 0.29 & $(0.05)$ & 0.07 & 1.26 & 4.81 \\
SIZE (log) & 19.15 & 19.24 & 24.73 & 13.14 & 2.63 & $(0.07)$ & 2.64 \\
\hline
\end{tabular}

ESG—economic, social and governance disclosure; ECN—economic performance; ROA—return on assets (firm profitability). Source: Alsayegh et al. (2020).

Table 4 presents the Spearman correlation matrix for the dependent and independent variables in our sample. The initial analysis suggests that the ESG disclosure score is positively correlated to ECN performance, firm accounting performance, leverage and size. Further, the value for each predictor variable is well within the acceptable upper limit, thereby signifying that the variables do not have any multicollinearity issues. 
Table 4. Spearman correlations matrix.

\begin{tabular}{|c|c|c|c|c|c|}
\hline Coefficient & ESG & $\mathrm{ECN}$ & LEV & ROA & SIZE \\
\hline ESG & 1 & & & & \\
\hline $\mathrm{ECN}$ & $\begin{array}{c}0.645885^{* * *} \\
(0.0001)\end{array}$ & 1 & & & \\
\hline LEV & $\begin{array}{c}0.056573^{* * *} \\
(0.0001)\end{array}$ & $\begin{array}{c}-0.029334^{* * *} \\
(0.0016)\end{array}$ & 1 & & \\
\hline ROA & $\begin{array}{c}0.049422^{* * *} \\
(0.0001)\end{array}$ & $\begin{array}{c}0.129146^{* * *} \\
(0.0001)\end{array}$ & $\begin{array}{c}-0.221753 * * * \\
(0.0001)\end{array}$ & 1 & \\
\hline SIZE & $\begin{array}{c}0.250733^{* * *} \\
(0.0001)\end{array}$ & $\begin{array}{c}0.246506^{* * * *} \\
(0.0001)\end{array}$ & $\begin{array}{c}0.071716^{* * *} \\
(0.0001)\end{array}$ & $\begin{array}{c}-0.206179 * * * \\
(0.0001)\end{array}$ & 1 \\
\hline
\end{tabular}

*** indicatesthat the correlation is significant at the 0.01 levels, respectively (two-tailed).

Table 5 summarizesthe results of the panel data regression to predict the factors driving ESG disclosure scores according to three-panel approaches-the pooled OLS, the fixed-effect and the random-effect models.

Table 5. Determinants ofenvironment, social and governance(ESG) sustainability disclosure.

\begin{tabular}{cccc}
\hline Variable & OLS & Fixed-Effect & Random-Effect \\
\hline ECN & $0.43187^{* * *}$ & $0.43810^{* * *}$ & $0.43198^{* * *}$ \\
Leverage & $(23.262)$ & $(61.375)$ & $(41.273)$ \\
& $5.57355^{* * *}$ & $5.24345^{* * *}$ & $5.52729^{* * *}$ \\
Profitability (ROA) & $(31.514)$ & $(35.621)$ & $(32.312)$ \\
& $7.61210^{* * *}$ & $11.6920^{* * *}$ & $7.59596^{* *}$ \\
Size & $(7.234)$ & $(9.213)$ & $(6.271)$ \\
& $0.431877^{* * *}$ & 0.731119 & $0.413742^{* * *}$ \\
Intercept & $(32.187)$ & $(40.823)$ & $(33.651)$ \\
& $29.9667^{* * *}$ & $68.9101^{* * *}$ & $29.9127^{* * *}$ \\
AutoR(1) & $(9.87)^{* * *}$ & $(11.564)$ & $(9.459)$ \\
& $0.924379^{* * *}$ & $0.587107^{* * *}$ & $0.92397^{* * *}$ \\
Cross-section & $(97.686)$ & $(70.485)$ & $(96.309)$ \\
dummies & No & Yes & No \\
Year dummies & Yes & Yes & Yes \\
Industry dummies & Yes & No & Yes \\
R-squared & 0.92956 & 0.948536 & 0.929565 \\
F-statistic & $22,515.54$ & 121.1037 & $19,298.59$ \\
Durbin-Watson & 2.107544 & 2.048509 & 2.106878 \\
Observations & 8700 & 8700 & 9954 \\
\hline
\end{tabular}

T-statisticsare shown in brackets. ${ }^{* *},{ }^{* * *}$ indicatesthat the correlation is significant at the 0.05 and 0.01 levels, respectively (two-tailed). ESG-environment, social and governance disclosure; ECN-economic performance.

The results in columns 1 (OLS), 2 (fixed effect) and 3 (random effect) in Table 5 provide evidence that the economic $(\mathrm{ECN})$ performance in our Asian sample firms is statistically significant in influencing the level of ESG sustainability disclosure, thereby validating the first hypothesis $\left(\mathrm{H}_{1}\right)$. The ECN sustainability performance shows highly significant coefficients of $0.43,0.44$ and 0.43 with the Adjusted R-squared values of $0.93,0.94$ and 0.93 for the three-panel approaches (OLS, fixed effect and random effect), respectively. Similar to the findings by Hummel and Schlick (2016) and Deegan (2002), our study provides evidence that firms with higher economic sustainability performance disclose more ESG information to remain legitimate and in line with social responsibilities.

Concerningthe second hypothesis $\left(\mathrm{H}_{2}\right)$, corporate financial performance (ROA) is also found to be significantly positive with ESG disclosure. Unlike studies by Chih et al. (2010) and Dyduch and Krasodomska (2017) that did not find a significant link between corporate financial performance and CSR, the positive ROA-ESG disclosure relationship found in this study is similar to the results found by Roberts (1992); Haniffa and Cooke (2005); 
Gamerschlag et al. (2010) and Menassa and Dagher (2020). As expected, organizations with relatively high financial performances disclose more ESG information to legitimize themselves and to minimize the possibility of adverse selection.

The study by Dyduch and Krasodomska (2017) found that leverage cannot explain differences in CSR disclosure initiatives. However, Table 5 in our study suggests that more highly leveraged firms disclose higher ESG information, thereby validating the third hypothesis $\left(\mathrm{H}_{3}\right)$. Similar to the findings found by Hummel and Schlick (2016), the positive LEV-ESG disclosure relationship in this study indicates that corporations with high leverage tend to disclose more ESG information. As Asian firms with higher debt financing are prone to be analyzedby debt holders, this situation will motivate them to be more efficient in their operational and organizational practices.

Following the results found in previous studies (namely, Bouten et al. 2011; Ali et al. 2017; Dyduch and Krasodomska 2017; Menassa and Dagher 2020), size also has a significant positive relationship with ESG disclosure, thereby validating the fourth hypothesis $\left(\mathrm{H}_{4}\right)$. Relative to smaller firms, large firms with more financial resources due to economies of scale can disclose their ESG practices more extensively. Large firm sizecould also be a factor to generate mimetic pressure because of more stakeholder groups to whom such firms are accountable. As larger firms are also more prone to be scrutinizedby various stakeholder groups, they are willing to voluntarily report more ESG information to reduce this coercive pressure.

In summary, our analysis provides evidence that firm characteristics (ECN performance, profitability, leverage and size) have an impact on the likelihood of Asian firms engaging in ESG sustainability disclosure. Asian firms with high economic performance, higher profitability, higher leverage and larger sizes are found to be more ESG disclosureminded. The significant results, as captured by variables related to social visibility, are consistent with the legitimacy theory that Asian firms disclose ESG information to legitimize their operations, thereby justifying their continued existence.

\section{Conclusions}

This paper examines the conditions that drive the ESG disclosure agenda among public listed firms in Asia. The findings reveal that highly socially visible organizations (i.e., in terms of economic performance, firm profitability, leverage and size) are usually prone to various pressures from the media, regulators and society at large. Hence, these organizations disclose more ESG information not only to discharge their accountability to various stakeholder groups that could hold them socially responsible but also to communicate and convince the public that they are meeting the social expectations of the latter to lessen those pressures. Firms disclose their sustainability practices to establish that their products and services are desirable and beneficial to different stakeholder groups, thereby achieving legitimate status in society.

Our findings provide valuable insights to corporate managers interested in exploiting strategies to legitimize ESG activities, particularly on factors that guide companies' ESG reporting. The results of this work are also useful for Asian policy regulators in formulating guidelines or regulations to further improve developing ESG reporting frameworks. Policy regulators in Asia may cooperate and establish a consensus on the ESG information to be reported to reduce the vast variation in ESG reporting among Asian publicly listed firms.

Our findings indicate important directions for future research. Besides examining the level of ESG reporting, future research may examine both the quantity and quality of ESG disclosure and its determinants. Future research can also examine the role of independent media and other stakeholders and of community and government regulators in driving the motivations for organizations to disclose ESG information. This aspect is deemed important because an organization's sustainability strategies and their ESG information disclosure is bounded by the institutional environment and by accountability requirements, a feature, which will influence the legitimacy status of firms. The role of these various 
stakeholder groups should promote an organization's image and reputation, not cause aloss of legitimacy.

Author Contributions: R.A.R., M.F.A. authors contributed equally to the data acquisition and writeup for the present study. Both authors have read and approved the manuscript.

Funding: The research received no external funding.

Institutional Review Board Statement: Not applicable.

Informed Consent Statement: Not applicable.

Data Availability Statement: The data presented in this study are available on request from the corresponding author.

Conflicts of Interest: The authors declare no conflict of interest.

\section{References}

Adams, Carol A., Wan-Ying Hill, and Clare B. Roberts. 1998. Corporate Social Reporting Practices in Western Europe: Legitimating Corporate Behavior? The British Accounting Review 30: 1-21. [CrossRef]

Ali, Waris, Jedrzej GeorgeFrynas, and Zeeshan Mahmood. 2017. Determinants of Corporate Social Responsibility (CSR) Disclosure in Developed and Developing Countries: A Literature Review. Corporate Social Responsibility and Environmental Management 24: 273-94. [CrossRef]

Alsayegh, Maha F., Rashidah Abdul Rahman, and Saeid Homayoun. 2020. Corporate Economic, Environmental, and Social Sustainability Performance Transformation through ESG Disclosure. Sustainability 12: 3190. [CrossRef]

Baba, Hanim Norza. 2017. The Determinants of Corporate Social Responsibility Disclosure: The Case of Malaysian Government-Linked Companies in Malaysia. SHS Web of Conferences 36: 29. [CrossRef]

Bajic, Steven, and B. Burcin Yurtoglu. 2018. Which aspects of CSR predict firm market value? Journal of Capital Market Studies 2: 50-69. [CrossRef]

Bouten, Lies, P. Everaert, Luc Van Liedekerke, Lieven De Moor, and Johan Christiaens. 2011. Corporate Social Responsibility Reporting: A Comprehensive Picture? Accounting Forum 35: 187-204. [CrossRef]

Branco, Manuel Castelo, and Lucia Lima Rodrigues. 2008. Factors Influencing Social Responsibility Disclosure by Portuguese Companies. Journal of Business Ethics 83: 685-701. [CrossRef]

Brooks, Cris, and Ioannis Oikonomou. 2018. The effects of environment, social and governance disclosures and performance on firm value: Are view of the literature in accounting and finance. British Accounting Review 50: 1-15. [CrossRef]

Campbell, John L. 2007. Why would corporations behave in socially responsible ways? An Institutional Theory of corporate social responsibility. Academy of Management Review 32: 946-67. [CrossRef]

Caputo, Fabio, Stefania Veltri, and Andrea Venturelli. 2017. A conceptual model of forces driving the introduction of a sustainability report in SMEs: Evidence from a case study. International Business Research 10: 39-50. [CrossRef]

Casey, Ryan J., and Jonathan H. Grenier. 2015. Understanding and Contributing to the Enigma of Corporate Social Responsibility (CSR) Assurance in the United States. Auditing: A Journal Practice \& Theory 34: 97-130. [CrossRef]

Chih, Hsiang-Lin, Hsiang-Hsuan Chih, and Tzu-Yin Chen. 2010. On the Determinants of Corporate Social Responsibility: International Evidence on the Financial Industry. Journal of Business Ethics 93: 115-35. [CrossRef]

Cuganesan, Suresh, Leanne Ward, and James Guthrie. 2007. Legitimacy Theory: A Story of Reporting Social and Environmental Matters within the Australian Food and Beverage Industry (5 July 2007). Paper presented at the 5th Asian Pacific Interdisciplinary Research in Accounting (APIRA) Conference, Auckland, New Zealand, July 8-10; Available online: https://ssrn.com/abstract=1360518 (accessed on 15 January 2019).

Dalal, Karishma K., and Nimit Thaker. 2019. ESG and Corporate Financial Performance: A Panel Study of Indian Companies. IUP Journal Corporate Governance 18: 44-59.

Deegan, Craig. 2002. Introduction: The legitimising effect of social and environmental disclosures-A theoretical foundation. Accounting, Auditing and Accountability Journal 15: 282-311. [CrossRef]

Deegan, Craig. 2006. Financial Accounting Theory. Sydney: McGraw-Hill.

Deegan, Craig M. 2019. Legitimacy theory: Despite its enduring popularity and contribution, time is right for a necessary makeover. Accounting, Auditing and Accountability Journal 32: 2307-29. [CrossRef]

Deegan, Craig, and Grant Samkin. 2009. New Zealand Financial Accounting. Sydney: McGraw-Hill.

Dyduch, Justyna, and Joanna Krasodomska. 2017. Determinants of Corporate Social Responsibility Disclosure: An Empirical Study by Polish Listed Companies. Sustainability 9: 1934. [CrossRef]

Escrig-Olmedo, Elena, Juana Maria Rivera-Lirio, and Maria Jesus Munoz-Torres. 2017. Integrating multiple ESG investors' preferences into sustainable investment: A fuzzy multi-criteria methodological approach. Journal Cleaner Production 162: 1334-45. [CrossRef]

Fifka, Matthias S. 2013. Corporate responsibility reporting and its determinants in comparative perspective-A review of the empirical literature and a meta-analysis. Business Strategy and the Environment 22: 1-35. [CrossRef] 
Gamerschlag, Ramin, Klaus Moller, and Frank H. M. Verbeeten. 2010. Determinants of voluntary CSR disclosure: Empirical evidence from Germany. Review of Managerial Science 5: 233-62. [CrossRef]

GIC Report. 2018-2019. Report on the Management of the Government's Portfolio. Available online: https://www.gic.com.sg/reports/ (accessed on 25 October 2020).

Gray, Rob, Reza Kouhy, and Simon Lavers. 1995. Corporate social and environmental reporting: A review of the literature and a longitudinal study of UK disclosure. Accounting, Auditing \& Accountability Journal 8: 47-77. [CrossRef]

Guthrie, James, and Lee D. Parker. 1989. Corporate Social Reporting: A Rebuttal of Legitimacy Theory. Accounting Business Research 19: 343-52. [CrossRef]

Hackston, David, and J. Markus Milne. 1996. Some determinants of social and environmental disclosure in New-Zealand companies. Accounting, Auditing and Accountability Journal 9: 77-108. [CrossRef]

Hahn, Rudiger, and Michael Kuhnen. 2013. Determinants of Sustainability Reporting: A Review of Results, Trends, Theory and Opportunities in an Expanding Field of Research. Journal of Cleaner Production 59: 5-21. [CrossRef]

Haniffa, Roszaini M., and Terry E. Cooke. 2005. The impact of culture and governance on corporate social reporting. Journal of Accounting and Public Policy 24: 391-430. [CrossRef]

Herbohn, Kathleen, Ru Gao, and Peter Clarkson. 2019. Evidence on whether banks consider carbon risk in their lending decisions. Journal of Business Ethics 158: 155-75. [CrossRef]

Herzig, Christian, and Stefan Schaltegger. 2006. Corporate sustainability reporting: An overview. In Sustainability Accounting and Reporting. Edited by Schaltegger Stefan, Martin Bennett and Roger L. Burritt. Dordrecht: Springer, pp. 301-24.

Ho, Prudence. 2020. Leveraged Debts Investors Push Borrowers on ESG Disclosures. February. Retrieved on 12 January 2021. Available online: https:/ / www.reuters.com/article/leveraged-debt-investors-push-borrowers-idUSL8N2AD6OG (accessed on 5 January 2021).

Hooghiemstra, Reggy. 2000. Corporate communication and impression management-New perspectives why companies engage in corporate social reporting. Journal of Business Ethics 27: 55-68. [CrossRef]

Hossain, Mohammed, and Masrur Reaz. 2007. The determinants and characteristics of voluntary disclosure by Indian banking companies. Corporate Social Responsibility Environment Management 14: 274-88. [CrossRef]

Hummel, Katrin, and Christian Schlick. 2016. The Relationship between Sustainability Performance and Sustainability DisclosureReconciling Voluntary Disclosure Theory and Legitimacy Theory. Journal of Accounting and Public Policy 35: 455-76. [CrossRef]

Ioannou, Ioannis, and George Serafeim. 2017. The Consequences of Mandatory Corporate Sustainability Reporting. In Harvard Business School Research Working Paper No. 11-100. Boston: Harvard Business School.

Jackson, Gregory, Julia Bartosch, Emma Avetisyan, Daniel Kinderman, and Jette Steen Knudsen. Mandatory non-financial disclosure and its influence on CSR: An international comparison. Journal of Business Ethics 162: 323-42. [CrossRef]

Jain, Pankaj K., Archana Jain, and Zabihollah Rezaee. 2016. Value-relevance of corporate social performance: Evidence from short selling. Journal Management Accounting Research 28: 29-52. [CrossRef]

Jitmaneeroj, Boonlert. 2016. Reform priorities for corporate sustainability: Environmental, social, governance, or economic performance? Management Decision 54: 1497-521. [CrossRef]

Joshi, Ghanasham S., and Raju Laxman Hyderabad. 2018. Determinants of Corporate Social Responsibility Reporting in India. Journal of Management 6: 1-10. [CrossRef]

Magali, Geerts, Dooms Michael, and Stas Lara. 2020. Determinants of sustainability reporting in the present institutional context: The case of seaport authorities. Paper presented at IAME 2020 Conference, Hong Kong, China, June 10-13.

Meek, Gary, Clare Roberts, and Sidney Gray. 1995. Factors Influencing Voluntary Annual Report Disclosures by U.S., U.K. and Continental European Multinational Corporations. Journal of International Business Studies 26: 555-72. [CrossRef]

Menassa, Ellie, and Nancy Dagher. 2020. Determinants of corporate social responsibility disclosure of UAE national banks: A multi-perspective approach. Social Responsibility Journal 16: 631-54. [CrossRef]

Mion, Giorgio, and Christian R. Loza Adaui. 2019. Mandatory nonfinancial disclosure and its consequences on the sustainability reporting quality of Italian and German companies. Sustainability 11: 4612. [CrossRef]

Mousa, Gehan, and Naser Hassan. 2015. Legitimacy Theory and Environmental Practices: Short Notes. International Journal of Business and Statistical Analysis 2. [CrossRef]

Pfeffer, Jeffrey, and Gerald Salancik. 1978. The External Control of Organizations: A Resource Dependence Perspective. New York: Harper and Row.

Reverte, Carmelo. 2009. Determinants of corporate social responsibility disclosure ratings by Spanish Listed firms. Journal of Business Ethics 17: 120-36. [CrossRef]

Rezaee, Zabihollah. 2016. Business sustainability research: A theoretical and integrated perspective. Journal Accounting Literature 36: 48-64. [CrossRef]

Roberts, Robin W. 1992. Determinants of corporate social responsibility: An application of stakeholder theory. Accounting Organizational Society 17: 251-66. [CrossRef]

Sanchez-Planelles, Joaquin, Marival Segarra-Oña, and Angel Peiro-Signes. 2021. Building a Theoretical Framework for Corporate Sustainability. Sustainability 13: 273. [CrossRef]

Simnett, Roger, Ann Vanstraelen, and Wai Fong Chua. 2009. Assurance on Sustainability Reports: An International Comparison. Accounting Review 84: 937-67. [CrossRef] 
Suchman, Mark C. 1995. Managing legitimacy: Strategic and institutional approaches. Academic Management Review 20: 571-610. [CrossRef]

Taliento, Marco, Christian Favino, and Antonio Netti. 2019. Impact of Environmental, Social, and Governance Information on Economic Performance: Evidence of a Corporate 'Sustainability Advantage' from Europe. Sustainability 11: 1738. [CrossRef]

Walden, W. Darrell, and Bill N. Schwartz. 1997. Environmental Disclosures and Public Policy Pressure. Journal of Accounting and Public Policy 16: 125-54.

Wang, Jianling, Lin Song, and Shujie Yao. 2013. The Determinants of corporate social responsibility disclosure: Evidence from China. Journal of Applied Business Research 29: 1833-47. [CrossRef]

Weber, Olaf. 2012. Environmental credit risk management in banks and financial service institutions. Business Strategy and the Environment 21: 248-63. [CrossRef]

Weber, Olaf. 2014. Environmental, Social and Governance Reporting in China. Business Strategy Environment 23: 303-17. [CrossRef]

Xie, Jun, Wataru Nozawa, Michiyuki Yagi, Hidemichi Fujii, and Shunsuke Managi. 2019. Do Environmental, Social, and Governance Activities Improve Corporate Financial Performance? Business Strategy E the Environment 28: 286-300.

Zhao, Changchong, Yu Guo, Jiahai Yuan, Mengya Wu, Daiyu Li, Yiou Zhou, and Jiangang Kang. 2018. ESG and corporate financial performance: Empirical evidence from China's listed power generation companies. Sustainability 10: 2607. [CrossRef] 